\title{
Получение линий растений мутантов и анализ полученных популяций после геномного редактирования по гену $\mathrm{Nud}$ у ячменя
}

\author{
Короткова А.М. ${ }^{1}$, Колосовская Е.В. ${ }^{1}$, Герасимова С.В. ${ }^{1}$, Кукоева Т.В. ${ }^{1}$, Хлесткина Е.К. ${ }^{1,2}$ \\ ${ }^{1}$ ИЦиГ СО РАН, Новосибирск, Россия \\ ${ }^{2}$ ВИР, Санкт Петербург, Россия \\ *e-mail: korotkova@bionet.nsc.ru
}

Ключевые слова: CRISPR/Cas, ячмень, Nud, геномное редактирование, пленчатость, голозерность

Мотиващия и цель: Методы геномного редактирования растений бурно развиваются в последние годы [1], однако работ по редактированию ячменя не много, что обусловлено сложностью редактирования геномов однодольных растений [2].

После проведения геномного редактирования ячменя методом CRISPR/Cas по гену Nud были получены ряд мутантов, несущих целевые и нецелевые муации. Среди многообразия мутантов были отобраны те, что несут только мутации в гене Nud и немутантны по остальным генам. Ген Nud является транскрипционным фактором, ответственным за образование липидного слоя на поверхности зерна, который, при созревании, приводит к прилипанию чешуек к зерну и формированию свойства пленчатости зерна. Целью работы был отбор голозерных линий растений с мутациями в гене Nud.

Meтоды и алгоритмы: С помощью двух разных направляющих-РНК (Nud45 и Nud50) методом геномного редактирования CRISPR/Cas, нами были получены растения T0 с различными мутациями в четырех генах: Nud (целевой), Win1 и двух безымянных генах расположенных на хромосомах 6H и 7Н ячменя (нецелевые мутации). Геномное редактирование проводилось на сорте Golden promise. Всего было получено 50 растений T0 Nud45 и 49 растений Nud50, среди которых встречались и гетерозиготы и дикий тип и растения с биаллельной мутацией. Во второе поколение Т1 были отобраны интересующие нас мутации для выведения их в гомозиготное состояние. По 9 растений из группы Nud45 и Nud50. В том числе была выделена линия дикого типа в качестве контрольной группы. Растения были проверены на наличие трансгена и среди нетрансгенных выделены три линии Nud50 с мутациями в гене Nud $(-3),(+1)$ и (-1). Все три линии растений несут в себе свойство голозерности. Растения были высажены в теплице. Из каждого растения выделена ДНК. При помощи секвенирования было подтверждено единообразие последовательностей гена Nud в каждой линии. Проведен сноповой анализ и сравнение с контролем.

Pезультаты: В результате отбора были выделены три линии растений с мутациями в гене Nud (-3), $(+1)$ и $(-1)$. Все три линии растений несут в себе свойство голозерности. Выполнено сравнение трансформантов с контрольными растениями по параметрам снопового анализа. Отобраны мутанты из группы Nud45. Обработка результатов второй группы растений еще в процессе.

Исследование выполнено за счет гранта Российского научного фонда (проект № 16-14-00086).

Список литературь

1. Korotkova A.M., Gerasimova S.V., Khlestkina E.K. Current achievements in modifying crop genes using CRISPR/Cas system. Vavilov Journal Genetics Breeding. 2019. 23(1). P. 29-37.

2. Gerasimova S.V., Khlestkina E.K., Kochetov A.V., Shumny V.K. Genome editing system CRISPR/CAS9 and peculiarities of its application in monocots. Russ. J. Plant Physiol. 2017. V. 64(2). P. 141-155. 